\title{
Nephrostomy Site
}

National Cancer Institute

\section{Source}

National Cancer Institute. Nephrostomy Site. NCI Thesaurus. Code C122648.

A surgically created external opening into the renal pelvis. 